ESJ Social Sciences

\title{
Risk Assessment Providing Solid Grounds For Strategic Management In The Insurance Industry
}

\author{
Prof. Ljubomir Drakulevski, PhD, Full professor \\ Tamara Kaftandzieva, MA, PhD Scholar
}

Faculty of Economics - Skopje

Ss. Cyril and Methodius University in Skopje, Republic of North Macedonia

Doi:10.19044/esj.2021.v17n15p38

Submitted: 02 April 2021

Accepted: 04 May 2021

Published: 31 May 2021
Copyright 2021 Author(s)

Under Creative Commons BY-NC-ND

4.0 OPEN ACCESS

Cite As:

Drakulevski Lj. \& Kaftandzieva T. (2021). Risk Assessment Providing Solid Grounds For Strategic Management In The Insurance Industry.

European Scientific Journal, ESJ, 17(15), 38. https://doi.org/10.19044/esj.2021.v17n15p38

\begin{abstract}
The insurance industry is undergoing more turbulence than any other industry since nowadays it is faced with a variety of strategic risks-emerging threats and challenges: change in regulation, customer behavior, distribution channels, competition, and new innovative technologies. The aim of this study is to propose strategic management directions towards risk assessment in the insurance companies, which could implicate the overall performance of many engaged in this sector. Given the growing importance of the insurance companies, profitability is considered as one of the key performance metrics which is under major influence of internal factors. This type of analysis is an important tool in determining the quick and decisive response of the managers to important new challenges and opportunities, especially in absence of a risk management regulatory framework. For this purpose, the data of 11 non - life insurance companies operating in North Macedonia from the period 2012 2019 is examined. The estimated model with random effects on panel data suggests a negative and significant influence of the loss ratio, the expense ratio, the retention rate, and the premium to surplus ratio on the profitability of non - life insurers, as measured by the return on assets (ROA), whereas the size has a positive impact on the profitability. The influence of remaining variables on the profitability was not found to be statistically significant. The obtained results were alighed in recommendations which can be used to potential future improvement and viable business strategies considering the
\end{abstract}


specific and vulnerable Macedonian insurance context.

Keywords: Strategic Management, Non - Life Insurance, Profitability; Firm - Specific Factors, Risk Management

\section{Introduction}

The insurance sector plays an important role within the financial sector in almost all developed and developing countries, contributing to economic development, increase of national wealth, efficient allocation of resources, reducing transaction costs, creating liquidity and enabling economies of scale in the investment activities (Haiss and Sümegi, 2008). As a result, the financial performance of the insurance companies is of great importance to various interested parties, such as policyholders, agents, shareholders, regulators, supervisors as well as policymakers. In this context, one question that naturally arises is how it can be measured, and what factors determine the profitability of the insurance companies.

No company is isolated but operates in a broader, dynamic system of mutual interactions. Factors that affect the profitability of insurance companies can be classified as internal or external factors. Due to their systemic nature, external factors affect the performance of the entire insurance sector to a certain extent. However, the differences in performance between individual companies operating in the same insurance sector can be explained by the influence of internal, firm-specific factors. Internal factors are dominant in determining financial results; they are specific to each company and are under the influence of the management. Profitability is one of the key determinants for success and a prerequisite for increasing competitiveness and market share. Also, profits attract investors and improve the level of solvency. The financial performance of insurance companies is also relevant in the macroeconomic context, as the insurance industry contributes to fostering economic growth and stability (Burca and Batrinca, 2014). When taking into consideration the insurance companies, the profitability should be analyzed in light of the concept of risk. Risk assessment is a research area that is gaining momentum, especially when taking into account the increased attention to the concept of risk in the business environment.This is in fact due to the greater awareness of risk after the series of corporate scandals, the global financial and economic crisis, and the intensification of regulatory requirements in the EU, including the Solvency II directive.

The coherent study of risk assessment in insurance companies, and the relationship between firm - specific factors, and profitability has recently enjoyed an increasing interest among researchers. Yet, despite the rising popularity of the topic, we have identified a lack of recent findings in the Macedonian non - life insurance sector, which has motivated us to enrich the 
literature in this area. The main aim of this paper is to examine how firm specific factors affect profitability and what are the strategic implications that arise from that relationship. Accordingly, knowing the direction and intensity of the impact of various internal factors is an important pillar in the process of making business and strategic decisions.

The Macedonian insurance sector is still small, with its total assets accounting for 3.4\% of GDP (3.3\% in 2018). Despite the accelerated growth in life insurance, non - life insurance is still prevailing $(65.4 \%$ of the total assets in the insurance sector), within which, the motor third party liability insurance still being the most dominant class of insurance 52.3\%. Although the great potential for future development is evident, Macedonian insurance has been improving slowly, lagging behind the EU level. In 2019, the insurance density rate measured as gross written premium per capita amounted to 5,099 Macedonian Denars (82.9 EUR), whereas the penetration rate (GWP / GDP) was $1.5 \%$. However, the penetration, and density rates correlate with the standard of living and the attitude towards understanding, accepting and reduction of risk (NBRNM, 2019).

Guided by the targets and indicators used by the researchers in this field as well as those proposed by IMF (2003) and OECD (2016), within the scope of this paper a set of firm - specific indicators is defined, and their effect on the profitability of the Macedonian non - life insurance companies in the period between 2012 and 2019 is examined. This paper contributes to the existing literature by shedding light on the recent analysis of the influence of firm - specific factors on the profitability among non-life insurance companies to provide evidence for drawing coherent conclusions. Furthermore, this approach allows discussion of the results from a managerial point of view, and enables the concepts of profitability in the insurance sector and risk assessment to be linked with strategic management. Therefore, the obtained results are beneficial from both theoretical and empirical perspectives.

The rest of the paper is structured as follows. Section 2 reviews the related literature. Section 3 defines the variables included in the empirical analysis, lists the sources of the data and presents the proposed model. Section 4 presents and discusses the obtained results. Section 5 is the conclusion.

\section{Literature review}

As an integral part of the financial sector, insurance companies have always posed a challenge for researchers around the world, due to their significant implications on the economic, social, and political spheres. Profitability, as one of the key goals of every financial institution, is a constantly hot issue, addressed by numerous studies. However, the relationship of the firm-specific factors and profitability has recently enjoyed 
increased interest among researchers. Several previous studies related to the determinants of the profitability of the non-life insurance companies were analyzed in order to observe the general trends in different countries and regions.

One of the first studies in this area analyzed the determinants of insurance companies' performance during the period 1986-1999 in the UK (Shiu, 2004). By empirically testing the economic and firm-specific variables, the author found that liquidity, unexpected inflation, interest rate levels, and core business profits were statistically significant determinants of insurance performance in the UK, revealing a positive correlation with interest rates, return on equity, solvency margins and liquidity, as well as a negative correlation with inflation and reinsurance dependence.

Using data from 1993 to 1997, Adams and Buckle (2003) conducted an empirical analysis of the determinants of the financial performance of the insurance companies in Bermuda. The findings indicate positive financial performance for companies with high leverage and low liquidity. Also, the financial performance positively correlates with the underwriting risk, while the size and scope of the company's operations are not significantly correlated to the financial performance. These researchers are among the few who have found a positive impact of underwriting risk on profitability.

A study conducted by Lee (2014) focuses on firm - specific factors and macroeconomic indicators that affect the profitability of Taiwanese non life insurance companies. In this study, the panel data are analyzed over the period from 1999 to 2009, and profitability is measured by operating profit margin and ROA. According to the empirical results, the low loss ratio, the low use of reinsurance, the low expense ratio, and the positive return on investment have a positive effect on the profitability. Out of the macroeconomic variables, only the rate of economic growth has a significant impact on the operating profit margin. Market share has a negative effect on the operating profit margin, and financial leverage is reflected in the lower market value of the company, thus being significantly and negatively correlated with ROA.

Research on this topic has been conducted among the countries of the region, and their findings are largely consistent. The study by Pervan et al., (2013) conducted on the Macedonian non - life insurance market in the period 2002-2011 included both firm - specific and macroeconomic factors as determinants of insurers' performance. According to their findings, the expense ratio, the loss ratio, the economic growth, and the inflation play a major role in determining the profitability of the Macedonian non - life insurance sector. Analysis of the Serbian non - life insurance companies in the period from 2006 to 2013 indicates a significant and negative impact on the financial leverage, the retention rate, and the combined ratio on the 
profitability as measured by the return on assets, while the influence of the premium growth rate, return on investment and company size is significant and positive (Kočović et al., 2014). Covering the Serbian non-life insurance sector from 2010 to 2015, Pjanic et al. (2018) examined the influence of the firm - specific factors: the company's size, the asset growth, the premium growth, the liquidity ratio, the debt ratio, the underwriting risk measured by the premium to surplus ratio, operating costs, financial leverage, and total revenues on the profitability. They have found that the increase in the premiums, the debt ratio, the operating costs and the share of the profit in total revenues have the greatest impact on the profitability in non - life insurance companies, measured by ROA. The experience from Croatia, on the other hand, indicates an existence of a dynamic insurance market, with potential for greater development. According to the study conducted in the period from 2003 to 2009 which covers insurance - specific, industry - specific and macroeconomic variables; the ownership, the expense ratio, and the inflation were found to have a negative and significant influence on the profitability, while past performance has a positive and a significant impact on the profitability measured by ROA (Pervan and Pavić Kramarić, 2010). Covering the same period, another research was conducted on the Croatian insurance market, where in addition to the factors from the internal environment, external economic factors from the wider environment were analyzed as well. The results showed a significant impact of company size, underwriting risk, inflation, and return on equity on profitability (Ćurak et al., 2011). A similar approach to the analysis of the internal and external environment was applied by Kozak (2011), who analyzed the influence of the macroeconomic and microeconomic variables on the profitability and cost efficiency of the non life insurance companies in Poland during the process of integration into the European Union between 2002 and 2009. This period was characterized by an increase in the number of companies controlled by foreign investors, which has led to an increase in the gross written premium and accordingly, an increase in profitability. Besides, GDP growth and the market share of foreign - owned companies have a positive effect, while higher operating costs and the share of motor insurance in the company's portfolio have a negative effect on the financial performance on the non - life insurance companies.

The empirical findings of a panel data study on 198 non - life insurance companies in nine EU countries for the years 2004-2012 suggest that profitability is negatively affected by the size of the assets, underwriting activity measured by the combined ratio, and by strategic choices such as internationalization (when the shareholders are foreign companies or groups) and diversification (mixed companies operating in non - life and life insurance), while being positively affected by the volume of the reserves and the asset turnover. Regarding the macroeconomic variables, there is an inverse 
relationship between profitability and the growth rate of the insurance market, which may be due to increased competition (Moro and Anderloni, 2014). According to the authors, the three main areas that constitute core insurance activity: insurance, financial and reinsurance activities strongly influence the profitability, although the impact of the reinsurance is neither negative, nor positive.

Malik (2011) explored firm-specific factors on a sample of 34 insurance companies in Pakistan for the period 2005-2009. According to the obtained results, the volume of capital, and the size of the company are positively and significantly related to profitability, whereas a significant but inverse relation was observed between both the loss ratio and the leverage ratio with the profitability.

Burca and Batrînca (2014) examined the factors influencing the financial operations of 21 insurance companies on the Romanian insurance market during the time period 2008-2012 within the panel model with fixed effects. The determinants that positively affect the financial performance of non - life insurance companies in Romania are the size of the company, the retention rate, and the solvency margin, whereas financial leverage, premium growth, and loss ratio have a negative impact on the profitability measured by ROA.

The main results of the study of the key determinants of the profitability of non - life insurance companies in Turkey in the period from 2006 to 2013 show a positive correlation between the profitability and premium growth rate and a negative correlation with the age of the company, the loss ratio, and the current ratio. The results of the study have several implications: larger non-life insurance companies are more profitable compared to smaller ones, low risk of insurance leads to higher profitability, and lower liquidity implies better financial results (Kaya, 2015).

In the study conducted on nine insurance companies in the period from 2005 to 2009 in Ethiopia, Mehari and Aemiro (2013) found that leverage, besides the size of the company, has a significant and positive impact on profitability, while the loss ratio is statistically significant and negatively correlated with ROA. Tegegn et al., (2020) have recently conducted a study in the Ethiopian insurance market for the period between 2005 and 2016, and have examined the effects of firm-specific factors on profitability with ROA as a proxy. The authors developed random effects model for panel data analysis, and identified a positive relationship between premium growth rate and size and profitability.

\section{Methodology and model specification}

This study covers a period of eight years between 2012 and 2019, and the sample is comprised of all 11 non - life insurance companies operating in 
North Macedonia. Annual data were used in the study, obtained from secondary data resources: the annual financial statements and accompanying notes as well as the annual reports of the Insurance Supervision Agency. Although the Macedonian insurance market has faced turbulences during the observed years, when several acquisitions took place, panel data analysis proved to be the preferred method for performing the analysis. Namely, during the observed period, the total of 11 non-life insurance companies operated on the market, and despite the several acquisitions, and changes in ownership structures, the business, assets, and liabilities of the acquired companies continued unaffected by the transactions.

The performance analysis of the non - life insurance companies in North Macedonia was carried out using a set of firm - specific indicators, related to the capital adequacy, the asset quality, the reinsurance, the underwriting performance, and the risk, the reserves, and the leverage, as proposed by the IMF (2003) and OECD (2016).The analysis was proposed in this manner in absence of structured adopted regulation and risk management procedure, implemented at country level (such as Solvency II regulation framework in EU). The variables used in the analysis were selected and specified after a thorough examination of the relevant literature findings and previous empirical studies in the area, and in accordance with data availability. The dependent variable in this study is profitability, measured by ROA (return of assets). The eight independent variables used as determinants of the profitability of the non-life insurance companies that operate in North Macedonia are: size of the company, loss ratio, expense ratio, insurance leverage ratio, premium growth rate, motor insurance, premium retention ratio and insurance capacity. The variables alongside their measurement method are presented on Table 1.

Table 1. Dependent and independent variables

\begin{tabular}{|l|l|l|}
\hline Notation & Variable & Measurement method \\
\hline $\mathrm{Y}$ & Return on assets (ROA) & Profit after tax/total assets \\
\hline $\mathrm{X} 1$ & Size of the company & Natural log of total assets \\
\hline $\mathrm{X} 2$ & Loss ratio & Incurred claims/earned premium \\
\hline $\mathrm{X} 3$ & Expense ratio & Operating expenses/earned premium \\
\hline $\mathrm{X} 4$ & Insurance leverage ratio & Net technical reserves/equity \\
\hline $\mathrm{X} 5$ & Premium growth rate & (Premium $\mathrm{t}$ - premium $\mathrm{t}-1$ )/premium $\mathrm{t}-1$ \\
\hline $\mathrm{X} 6$ & Motor insurance & Motor premium/total premium of the company \\
\hline $\mathrm{X} 7$ & Premium retention ratio & Net earned premium/gross earned premium \\
\hline $\mathrm{X} 8$ & Insurance capacity & Net premiums/equity \\
\hline
\end{tabular}

Source: Authors’ calculation

Financial performance is a universal indicator of the company's ability to generate profit and therefore serves as a measure of good business performance. The return on assets (ROA) was chosen as the proxy to measure 
profitability performance. Return on assets is an indicator of how profitable the company is relative to its total assets and shows the management efficiency of utilizing the assets to generate earnings (Crosson et al., 2008). The majority of authors within the framework presented in the Literature review used ROA in analyzing the profitability of the non-life insurance companies. Although the companies are not immune to changes that affect the entire insurance market, the fluctuations observed between insurance companies are mainly due to the internal changes and conditions, i.e. firm - specific factors (Malik, 2011). Therefore, determining those factors and their relationships with profitability is of great importance to the business. The selection of the independent variables was made taking into account the available data, as well as the relevant literature and theoretical knowledge.

Size of the company is measured by the natural logarithm of the total assets in order to eliminate the extreme values in the data. Many authors have used this parameter in their analysis, although their findings are not consistent (Adams and Buckle, 2003; Shiu, 2004; Ćurak et al. 2011; Malik, 2011; Mehari and Aemiro, 2013; Kočović et al., 2014; Lee, 2014; Burca and Batrînca, 2014; Kaya, 2015; Pjanic et al., 2018; Tegegn et al., 2020). Major insurance companies are expected to respond quickly to the market changes and benefit from economies of scale (Shiu, 2004); however, they could also encounter inefficiency and ineffectiveness issues (Adams and Buckle, 2003). Having in mind the characteristics of the Macedonian insurance market, in this paper we propose a positive relationship between the size of the company and the profitability.

The loss ratio, also considered as a proxy for measuring underwriting risk shows the effective risk - taking in the insurance underwriting process and Adams and Buckle (2003); Malik (2011); Mehari and Aemiro (2013); Lee (2014); Burca and Batrînca (2014); (Kaya, 2015) have also used it in their respective analysis. Undertaking excessive risk in order to increase the market position, may affect the stability of the company through accumulation of losses, further indicating that the costs paid for claims exceed the premiums earned. In this study the loss ratio is calculated by dividing the incurred claims with the earned premium and its expected influence on the profitability is negative.

The loss ratio is often combined with the expense ratio, calculated as the ratio of the sum of the operating expenses (acquisition cost, administrative costs and other technical charges) to the earned insurance premiums. Basically, the expense ratio compares the expenses incurred when underwriting a policy (the costs of acquiring, writing and servicing insurance) with the revenues expected from it. The lower the expense ratio, the more premiums are earned in comparison with the expenses paid in generating or supporting the premiums, hence the inverse relationship between expense ratio 
and profitability is expected. Other authors have used this indicator in their analysis as well (Pervan and Pavić Kramarić, 2010; Pervan et al., 2013; Lee, 2014).

The insurance leverage ratio is defined as reserves to equity and pose as an indicator of potential solvency issues. The amount of reserves should be carefully estimated to cover the potential liabilities from claims made on the underwritten policies. This ratio is one of the indicators used for analyzing the company's ability to meet and fulfill its financial obligations. Should the reserves be inadequately estimated, the insurer will be more reliant on policyholder surplus to cover the potential liabilities, and thus a greater risk of becoming insolvent emerges. Therefore, it is expected that the insurance leverage ratio will have negative effect on the profitability. Similar measure was used by Adams and Buckle (2003); Shiu (2004); Malik (2011); Burca and Batrînca (2014); Kočović et al. (2014); Kaya (2015).

Gross written premium is the main source of income for the insurance companies, which they earn from the basic insurance activity. The increase in the premium growth rate indicates both growth of the company and increase of the market share. However, in this process special attention should be paid on the underwriting process: risk assessment, risk selection, and pricing. Being excessively dedicated to increasing the market share, and to obtaining premium growth, may lead to negligence of the other important targets, such as solvency (Chen and Wong, 2004). Nevertheless, it is expected that the premium growth indicator will positively affect the profitability. Similar indicator was used by Mehari and Aemiro (2013); Burca and Batrînca (2014); Lee (2014); Kočović et al. (2014); Kaya, (2015); Pjanic et al. (2018); Tegegn et al. (2020) within the scope of their analysis.

Since the growth of the insurance market depends largely on the habits and attitudes of the people, it should be noted that on the Macedonian insurance market, the majority of people buy only the compulsory insurance for bodiliy injury or property damage caused by any event related to a car accident against third parties, regulated by law in North Macedonia. Therefore, even though the premium from motor insurance is guaranteed andfixed, determined by state laws, it is followed by high and frequent losses. Hence, a reverse relationship between the high share of motor insurance premium in the total premium and the profitability is expected. This indicator was used in the profitability analysis of Kozak (2011) and Kaya (2015).

Each insurance company transfers part of that risk to another insurance company in a process called reinsurance, in exchange for a premium, in order to hedge against risk, provide stability and increase its risk - taking capacity. This imposes the need to determine an appropriate level of retention, i.e. to what extent will the risks be retained in the company's own capacity, in order to reduce the risk of insolvency in the event of major, catastrophic damage 
(Shiu, 2004). The excess of risk is transferred to reinsurance with the goal to reduce the uncertainty of the frequency and magnitude of future losses, allowing insurance companies to hedge against potential economic shocks (Adams, 1996). The retention rate is included in this analysis because it reveals the risk - taking strategy. It is expected that the higher retention rate will positively affect the profitability. This indicator is often employed in other studies in the area of insurance (Lee, 2014; Kočović et al., 2014; Moro and Anderloni, 2014; Burca and Batrînca, 2014; Kaya, 2015).

Premium to surplus ratio is net premiums written, divided by policyholder surplus, which is the difference between the assets and liabilities of the non-life insurance company. This ratio indicates the capacity of an insurance company to underwrite new policies. The gap between the assets and the liabilities may be increased by effective risk management in the process of underwriting new policies: reducing losses and investing premiums. It is expected the higher premium to surplus ratio to be negatively associated with profitability. On the other hand, a low premium to surplus ratio is considered a sign of financial strength because the insurer possesses a larger capacity to write more policies. This indicator was also used by Pjanic et al. (2018) in their analysis.

The data of 11 non - life insurance companies operating on the Macedonian insurance market in the period between 2012 and 2019 were brought together to obtain 88 observed panel data sets. Since the data have both the cross-sectional and time-series dimensions, a panel data model was developed (Wooldridge, 2010). In this study, eight - year data exist for all cross - section units, therefore, the panel is balanced. The general form of a panel data regression model can be shown with this equation (Baltagi, 2005):

$$
Y_{i t}=\alpha+X_{i t}^{\prime} \beta+u_{i t} i=1, \ldots, N ; t=1, \ldots, T
$$

where $i$ denotes the cross - section dimension, and $t$ denotes the time dimension; $Y$ is the dependent variable; $X$ is the explanatory (independent) variable; $\beta$ is the regression coefficient of explanatory variable; $\alpha$ is the intercept; and $u$ is the error term.

Having in mind the specific model of this paper, the equation (1) can be translated into the following form:

ROA $_{i t}=\alpha_{i}+\beta_{1}$ SIZE $_{i t}+\beta_{2}$ LOSSRATIO $_{i t}+\beta_{3}$ EXPENSERATIO $_{i t}+\beta_{4}$ LEVERAGE $_{i t}+$

$\beta_{5}$ PREMIUMGROWTH $_{i t}+\beta_{6}$ MOTOR $_{i t}+\beta_{7}$ RETENTION $_{i t}+\beta_{8}$ CAPACITY $_{i t}+u_{i t}$ where $i$ is the index of non - life insurance companies; $t$ is the index of time periods (years); $\beta_{k}$ is the regression coefficient to be estimated ( $k$ is the index of explanatory variables and $\mathrm{k}=1,2,3, \ldots, 8)$ for each of the variables respectively. Based on the assumptions from the available observations, the widely used models in panel data analysis are: the pooled regression model, the fixed effects model, and the random effects model. The choice of the panel model specification is determined by the appropriate statistical tests. However, 
according to Wooldridge (2010), pooled OLS is employed when different sample is selected for each period of the panel data. In this paper, the same sample was observed through all periods, therefore fixed effects or random effects model are recommended. Based on the Hausman specification test results, the random effects model appeared to be mo appropriate model for this study than the fixed effects model, as the Chi-squared value is 12.3397 and the $p$-value is 0.1367. Furthermore, the Breusch - Pagan test $(p=0.1494)$ indicates the presence of homoscedasticity in the model, meaning the variance of the residual, or error term in the model is constant which suggests a level of consistency.

\section{Results and discussion}

The descriptive statistics for each of the predefined variables included in the panel set are presented in Table 2. The profitability indicator, ROA, ranges between $-30.1 \%$ and $9.7 \%$, with average value of $0.4 \%$. This result might indirectly suggest the key problem in the Macedonian insurance sector: insufficient pricing in order to increase or maintain market share, given the increased market competition.

Table 2. Descriptive statistics of variables

\begin{tabular}{|l|l|l|l|l|l|}
\hline & Mean & Median & Min. & Max. & Std. Dev. \\
\hline ROA & 0.004 & 0.016 & -0.301 & 0.097 & 0.065 \\
\hline Size & 20.786 & 20.859 & 19.925 & 21.63 & 0.517 \\
\hline Retention & 0.83 & 0.877 & 0.451 & 0.976 & 0.137 \\
\hline Motor insurance & 0.581 & 0.612 & 0.261 & 0.888 & 0.173 \\
\hline Loss ratio & 0.473 & 0.465 & 0.328 & 0.731 & 0.079 \\
\hline Leverage & 2.429 & 1.991 & 0.253 & 6.227 & 1.481 \\
\hline Premium growth & 0.055 & 0.041 & -0.122 & 0.52 & 0.107 \\
\hline Expense ratio & 0.587 & 0.565 & 0.381 & 0.95 & 0.123 \\
\hline Capacity & 2.326 & 2.028 & 0.297 & 6.037 & 1.405 \\
\hline
\end{tabular}

Source: Authors' calculation

In order to test if there is a potential for the multicollinearity of explanatory variables, the matrix of Pearson's correlation coefficients was calculated before the panel model design. Correlation coefficient values vary between -1 (perfect negative correlation) and 1 (perfect positive correlation). Since none of the computed correlation coefficients in Table 3 is greater than 0.7 it can be concluded that a high correlation between selected explanatory variables does not exist. 
Table 3. The matrix of Person's correlation coefficients

\begin{tabular}{|c|c|c|c|c|c|c|c|c|c|}
\hline & $\mathrm{ROA}$ & Size & Retention & $\begin{array}{l}\text { Motor } \\
\text { insurance }\end{array}$ & $\begin{array}{l}\text { Loss } \\
\text { ratio }\end{array}$ & $\begin{array}{l}\text { Levera } \\
\text { ge }\end{array}$ & $\begin{array}{l}\text { Premium } \\
\text { growth }\end{array}$ & $\begin{array}{l}\text { Expense } \\
\text { ratio }\end{array}$ & Capacity \\
\hline ROA & 1.000 & 0.470 & -0.308 & -0.368 & -0.554 & 0.258 & -0.209 & -0.129 & 0.264 \\
\hline Size & & 1.000 & -0.481 & -0.434 & -0.185 & 0.431 & -0.141 & 0.145 & 0.425 \\
\hline Retention & & & 1.000 & 0.445 & 0.205 & 0.089 & -0.013 & -0.524 & 0.088 \\
\hline $\begin{array}{l}\text { Motor } \\
\text { insurance }\end{array}$ & & & & 1.000 & 0.174 & -0.246 & 0.094 & -0.057 & -0.298 \\
\hline $\begin{array}{l}\text { Loss } \\
\text { ratio }\end{array}$ & & & & & 1.000 & 0.153 & 0.204 & -0.105 & 0.125 \\
\hline Leverage & & & & & & 1.000 & -0.114 & -0.474 & 0.583 \\
\hline $\begin{array}{l}\text { Premium } \\
\text { growth }\end{array}$ & & & & & & & 1.000 & 0.093 & -0.111 \\
\hline $\begin{array}{l}\text { Expense } \\
\text { ratio }\end{array}$ & & & & & & & & 1.000 & -0.502 \\
\hline Capacity & & & & & & & & & 1.000 \\
\hline
\end{tabular}

Source: Authors' calculation

According to the results obtained from the regression analysis, presented in Table 4, 66.3\% of the variance in the dependent variable (ROA) can be explained by the independent variables, meaning that the data fit the regression model, measured by the R-Squared indicator (coefficient of determination). The estimated model with random effects on the panel data reveal negative and significant influence of the loss ratio, the expense ratio, and the retention rate on the profitability at a statistically significant level of $1 \%$. According to the results, negative relationship between premium to surplus ratio (capacity), and profitability is determined at a statistically significant level of $5 \%$. On the other hand, there is a positive effect of the size of the company on the profitability measured with ROA, at a statistically significant level of $10 \%$. The other variables' influence is not taken into consideration, due to the lack of statistical significance at any of the observed levels.

Table 4. The results of random effects model

\begin{tabular}{|c|c|}
\hline Constant & -0.4723 \\
& $(0.479)$ \\
\hline Size & $0.0424^{*}$ \\
& $(0.022)$ \\
\hline Retention & $-0.1174^{* * *}$ \\
& $(0.042)$ \\
\hline Motor insurance & 0.0427 \\
& $(0.059)$ \\
\hline Loss ratio & $-0.5137^{* * *}$ \\
& $(0.059)$ \\
\hline Leverage & 0.0204 \\
& $(0.020)$ \\
\hline Premium growth & -0.0028 \\
& $(0.040)$ \\
\hline
\end{tabular}




\begin{tabular}{|c|c|}
\hline Expense ratio & $-0.1714^{* * *}$ \\
& $(0.051)$ \\
\hline Capacity & $-0.0169^{* *}$ \\
& $(0.021)$ \\
\hline R - Squared & 0.663 \\
\hline Adj. R - Squared & 0.614 \\
\hline F - statistic & 18.309 \\
\hline Prob ( F - statistic) & 0.000 \\
\hline Observations & 88 \\
\hline
\end{tabular}

Standard errors are reported in parentheses. *,**,*** indicates significance at the $90 \%, 95 \%$ and $99 \%$ level, respectively.

Source: Authors' calculation

The estimated values of the coefficients in the model suggest that the loss ratio, the expense ratio, the retention rate, and the premium to surplus ratio negatively affect the profitability of the non-life insurance companies in North Macedonia, whereas the influence of the size of the companies is positive.

The inverse relationship between the loss ratio (technical result), and profitability indicates that the companies with higher technical result are less profitable. This result is also in line with the findings of Malik (2011), Mehari and Aemiro (2013), Pervan et al., (2013), Burca and Batrînca (2014), Lee (2014), Kaya (2015), but contrary to the result of Adams and Buckle (2003) who concluded that companies that are less risk averse in the insurance acceptance process have better financial results. The higher loss ratio indicates that the premium income is not sufficient to cover the claims' expenses. This indicator can be implicitly correlated with the company's experience in providing a business quality and risk management. High loss ratio might be obtained when the insurer underestimates its clients' risk profiles, in an event of a natural disaster when the frequency of the claims is increased and when the operations are inefficient. Therefore, management should pay special attention to identifying, analyzing and quantifying this risk, and developing systems for its prevention, reduction, avoidance, and control. Insurance companies estimate the capacity in which they retain the risk on their own, and transfer the excess of risk to reinsurance. Those activities would provide greater protection and would ensure the stability of the earned premium, in order to mitigate the impact of the unexpected loss events.

The rationale for the negative influence of the expense ratio on the profitability is similar, given that both the loss ratio, and the expense ratio show the operational efficiency of the companies in performing their core business. Provided that these indicators are high, the key operative activities of the company may be regarded as less successful. Nevertheless, unless the expenditures for operational costs are followed by increase in the premium income, the performance of the management would be considered as poor; thereby negatively affecting the profitability. The findings are consistent with 
the findings of Pervan and Pavić Kramarić (2010); Pervan et al. (2013) and Lee (2014).

Reinsurance is considered among the most important activities of the insurance companies since it provides risk coverage and protection against catastrophic risks and large losses for the insurance companies, thus increasing their capacity, in exchange for a reinsurance premium. The retention ratio, as calculated in this paper, indicates that the company manages its own estimated risk without largely relying on reinsurance. The high retention rate reveal little gap between gross and net premium income, which contributes to higher profitability. However, this negative relationship between retention rate and ROA indicates lower dependence of the Macedonian non-life insurance companies on reinsurance and retaining the risks in their own coverage. Although, on one hand the reinsurance costs are low and adequate savings are achieved, the insurance companies are exposed to risks in relatively greater extent which would in turn harm the profitability (Shiu, 2004). The obtained result did not support the proposed hypothesis although it was in line with the findings of Lee (2014) and Kocovic et al. (2014), but in opposition to the results of Burca and Batrînca (2014).

A premium to surplus ratio is a measure of the financial strength of the insurance company, where surplus is the difference between the insurer's assets and liabilities. When premiums increase without a corresponding increase in policyholders' surplus, the capacity of the insurer to write new policies is decreasing, therefore the higher the ratio, the lower the capacity to write more policies. The excess of assets over liabilities refers to a higher capacity to underwrite new policies. If that is the case, the insurer should effectively manage the risks, by reducing losses from claims (therefore reducing the liabilities), and investing the premiums to achieve a return (therefore increasing the assets). In the obtained results of Pjanic et al. (2018) this indicator has not been statistically significant in the analysis.

Despite the inverse relationships between the aforementioned independent variables, and the dependent variable, the company's size positively affects the profitability. This relationship is understandable since the increase in the total assets is a significant factor affecting the profitability, measured by ROA. Larger companies realize the effects of economies of scale and better cost efficiency based on the control of the distribution channels, among other available capacities which enable them to cope better with the market conditions, as well as to achieve the effects of risk diversification (Kocovic et al., 2014). As a result, insurance companies operating in Macedonian non-life sector manage to successfully avoid bureaucracy, and to position themselves better in the market, thus enjoying higher benefits. The results are in line with the findings of Malik (2011), Curak et al. (2011), 
Mehari and Aemiro (2013), Burca and Batrinca (2014), Kaya (2015), Tegegn et al. (2020).

All things considered, managers in this dynamic, and turbulent environment face immense challenges to achieve positive financial results while at the same time maintaining the solvency. Although the aspiration of the insurance companies for a higher market position is clear, we must not forget that the increase in the volume of business activity is accompanied by an increase in liabilities to insurers; therefore it is necessary to allocate a relatively higher amount of technical reserves. If the premium growth is too aggressive, the insurance company is exposed to risks to the extent that they exceed the available technical and financial capacity, which may be one of the key reasons for its insolvency. Based on the obtained results from the analysis, and in order to achieve higher profitability, several implications for the managers arise. Managers should closely monitor the loss ratio, expense ratio and retention rate in terms of net premium income. Therefore, proper risk management mechanisms should be employed in order to produce an effective amount of premium income. Furthermore, an early warning system and holistic strategic management framework should be implemented.

Each company within the Macedonian insurance sector is striving towards greater profitability and at the same time faces the challenge to provide a sustainable competitive advantage over the other companies on the market. In order to achieving those strategic goals, a long term series of actions should be designed and implemented in terms of improving communication channels, operating systems, distribution channels, and managerial capacities and capabilities. The development of the growth strategies should be based on improved operations and should be oriented toward reducing the complexity, seeking new insights to create information advantage and transforming core operations to improve operational effectiveness. Among the changes the insurers face with major impact on their strategies are the changing customer behavior and new technologies that have to be adopted in order to keep track of the changing market conditions. Although the insurance sector is fairly traditional, the classical organization - centric, product driven model should be shifted towards customer - centric approach. Consequently, the insurers must understand customer behavior in order to provide tailored solutions to satisfy their needs and demands. Furthermore, the insurance companies should ensure accessibility of their services to customers and increase customer interaction. Taking this into consideration, the insurance services should be redefined; the insurance companies should be more flexible and manage the risks proactively. Nevertheless, the insurance companies should embrace the opportunities by defining unique capabilities to differentiate themselves from competitors, develop new products, distribution canals and methods. The success in achieving profitable growth amid economic, financial, and 
regulatory change is different for each company, depending on its unique characteristics and factors.

\section{Conclusion}

Non - life insurance companies in the Republic of North Macedonia operate in a small market, still developing and lagging behind European countries. Estimated results in suggested random effects model obtained from 11 non - life insurance companies in the period between 2012 and 2019 show statistically significant negative influence of the loss ratio, the expense ratio, the retention rate, and the premium to surplus ratio on the profitability as measured by the return on assets (ROA), whereas the size of the company positively affects the profitability of non - life insurers in North Macedonia.

The results of the study have several strategic implications for the managers in the Macedonian non - life insurance companies. First, the results indicate the necessity of identifying, analyzing, and quantifying the risks and developing systems to prevent, reduce, avoid or control them. This is especially important for the underwriting risk, as it is within the managerial control and influence. Second, the increase in market share and consequently the volume of business activity is accompanied by an increase in the company's liabilities to the insured. Therefore, it is required that the companies adequately estimate the level of technical reserves and operate within their capacity in order to prevent insolvency. Third, the company should set appropriate authorizations for employees, record and track the results of each individual client, set acquisition limits and procedures for approving transactions that involve new products or transactions that exceed the risk limits.

The dynamic environment, the advancement of the technology, globalization and financial innovation impose the need for proactive risk management. However, the insufficient readiness of Macedonian insurance companies to anticipate risks, and the absence of quantitative assessment and management techniques is one of the main problems of the Macedonian insurance sector. Therefore, in order to strengthen the stability of the insurance sector, the introduction of the EU Solvency II Directive is necessary, which would contribute to strengthening the capital positions and introducing riskbased capital requirements, as well as enhancing risk management and transparency of the insurance companies. The holistic risk - management framework which will eventually lead to better financial performance should be incorporated into the business activities and aligned with the corporate culture and the strategic goals. However, the adoption of the Solvency II framework will be a great challenge, especially for the companies that have weak management system and lack quantitative risk monitoring. 
In general, although every company in the insurance sector strives towards achieving higher profitability, many challenges arise along the way. First, the insurance sector faces a major challenge in acquiring new customers and retaining existing ones, mainly due to an increased competition in the last several years. Another challenge is the struggle to provide innovative insurance products and distribute them efficiently. Third challenge is the low public awareness of risks and the need for insurance alongside the low financial literacy. Fourth challenge is the insufficient trust in insurance companies due to delay in the process of payment of claims and fifth challenge is the unfair competition expressed through violation of existing tariffs of the insurance premium in order to artificially boost market share. However, with regards to their policyholders, the insurers should be more transparent in explaining and disclosing the insurance conditions and contribute to educating clients about insurance benefits, because a large part of the population considers insurance as an unnecessary expense.

On the positive side, the large number of policies concluded in 2019 is an indication that the public is becoming more aware of the need of securing its financial future in various ways. This means that despite the progress in the insurance, there is still room for stimulation of larger use of the benefits from the non-mandatory classes of insurance. However, in this process, much attention should be paid to ensuring sustainable profitable growth through prudent underwriting strategies, strict selection criteria, rational pricing policies, effective cost control for claims, and cost optimization.

\section{References:}

1. Adams, M. (1996). The reinsurance decision in life insurance firms: An empirical test of the risk-bearing hypothesis, Accounting \& Finance, 36(1), 15-30.

2. Adams, M. and Buckle, M. (2010). The determinants of corporate financial performance in the Bermuda insurance market, Applied Financial Economics, 3(2), 133-143.

3. Baltagi, B.H. (2005). Econometric Analysis of Panel Data, 3rd Ed.; John Wiley \& Sons Ltd., Chichester, UK

4. Burca, A. M. and Batrinca, G. (2014). The determinants of financial performance in the Romanian insurance market, International Journal of Academic Research in Accounting, Finance and Management Sciences, 4(1), 299-308.

5. Chen, R. and Wong, K. A. (2004), The determinants of financial health of Asian insurance companies, The Journal of Risk and Insurance, 71(3), 469-499.

6. Crosson, S. V., Needles, B. E. and Powers, M. (2008). Principles of accounting, 10th ed., Boston, MA: Houghton Mifflin. 
7. Ćurak, M., Pepur, S. and Poposki, K. (2011). Firm and economic factors and performance: Croatian composite insurers, The Business Review Cambridge, 19(1), 136-142.

8. Das, M. U. S., Podpiera, R., Davies, N. (2003). Insurance and issues in financial soundness, IMF Working Paper 03/138, International Monetary Fund, Washington, DC.

9. Haiss, P. and Sümegi, K. (2008). The relationship between insurance and economic growth in Europe: A theoretical and empirical analysis, Empirica, 35(4), 405-431.

10. Kaya, E. O. (2015). The effects of firm-specific factors on the profitability of non - life insurance companies in Turkey, International Journal of Financial Studies, 3(4), 510-529.

11. Kočović, J., Paunović, B. and Jovović, M. (2014). Determinants of business performance of non-life insurance companies in Serbia, Ekonomika preduzeća, 62(7-8), 367-381.

12. Kozak, S. (2011). Determinants of profitability of non - life insurance companies in Poland during integration with the European financial system, Electronic Journal of Polish Agricultural Universities, 14(1), 20-25.

13. Kwon, J. W. and Wolfrom, L. (2016). Analytical tools for the insurance market and macro-prudential surveillance, OECD Journal Financial Market Trends, 1, 1-47.

14. Lee, C.Y. (2014). The effects of firm specific factors and macroeconomics on profitability of property-liability insurance industry in Taiwan, Asian Economic and Financial Review, 4(5), 681691.

15. Malik, H. (2011). Determinants of insurance companies profitability: An analysis of insurance sector of Pakistan, Academic Research International, 1(3), 315-321.

16. Mehari, D. and Aemiro, T. (2013). Firm-specific factors that determine insurance companies'performance in Ethiopia, European Scientific Journal, 9(10), 245- 255.

17. Moro, O. and Anderloni, L. (2014). Non - life insurance economic performance - an empirical investigation, Journal of Economics \& Management, University of Economics in Katowice, 18, 159-177.

18. National Bank of the Republic of North Macedonia (2020). Financial stability report for the Republic of North Macedonia in 2019, available at

https://www.nbrm.mk/content/Regulativa/\%D0\%A4\%D0\%A1\%D0 \%A0_2019\%202.pdf (accessed 10.03.2021) 
19. Pervan, M. and Pavić Kramarić, T. (2010). Determinants of insurance companies' profitability in Croatia, The Business Review, Cambridge, 16(1), pp. 231-238.

20. Pervan, M., Poposki, K. and Ćurak, M. (2013). How Well Insurance Companies in Macedonia Perform? Recent researches in applied economics and management, Proceedings of the 5th WSEAS International Conference on Applied Economics, Business and Development, 457-463

21. Pjanić, M., Milenković, N., Kalaš, B. and Mirović, V. (2018). Profitability determinants of non - life insurance companies in Serbia, Ekonomika Preduzeca, 66(5-6), 333-345.

22. Shiu, Y. (2004). Determinants of United Kingdom general insurance company performance, British Actuarial Journal, 10(5), 1079-1110.

23. Tegegn, M., Sera, L and Merra, T. M (2020). Factors affecting profitability of insurance companies in Ethiopia: panel evidence, International Journal of Commerce and Finance, 6(1), 1-14

24. Wooldridge, J. M. (2010). Econometric Analysis of Cross Section and Panel Data. Cambridge, MA: MIT Press, Second Edition. 